\title{
PRINCÍPIO DE RAZÃO E O "CONHECIMENTO DAS CAUSAS": PENSAMENTO, REPRESENTAÇÃO E A POSSIBILIDADE DE SABER EM GERAL
}

\author{
Principle of REASON AND "KNOWLEDGe of \\ CAUSES": THOUGHT, REPRESENTATION AND \\ THE POSSIBILITY OF KNOWLEDGE IN GENERAL
}

Dax Moraes*

\begin{abstract}
RESUMO - O presente ensaio parte da conhecida tese de que "conhecer é conhecer a causa", a razão de ser. Sem recusar a correção desta tese, pretende-se determinar o âmbito e o alcance próprios da mesma levando-se em conta as suas limitações e as suas consequências sobre os modos moderno e contemporâneo de pensar. Deve ser o pensamento humano apenas representacional ou não? Se não é esse o caso, a referida tese afastará os filósofos do pathos originário, como devemos mostrar. Caso contrário, que nos resta pensar senão produtos do intelecto?

PALAVRAS-CHAVE - Causalidade. Pathos. Representação. Ciência. Angústia.

ABSTRACT - This essay starts at the well-known thesis according to which 'to know something is to know its cause', its reason. Not disagreeing with that at all, we mean to set the proper domain and reaching of the thesis once considering its limitations and effects for modern and contemporary way of thinking. Does may human thought be just representation, or not? If it does not, the thesis will actually make philosophers stay away from the originary pathos as we may show. If it does, what it is left to think about but mind productions? KEYWORDS - Causality. Pathos. Representation. Science. Anguish.
\end{abstract}

* Doutor em Filosofia pela Universidade Federal do Rio Grande do Norte (UFRN). Professor Adjunto III na Universidade do Estado do Rio Grande do Norte, curso de Filosofia (CaC/UERN). Endereço: Rua São Cristóvão, 95, ap. 302, Lagoa Nova, Natal-RN, CEP 59.056-290.<oejeblik@yahoo.com.br>.

\begin{tabular}{|l|l|l|l|l|l|}
\hline Veritas & Porto Alegre & v. 57 & n. 2 & maio/ago. 2012 & p. 163-193 \\
\hline
\end{tabular}


Aristóteles (2002, p. 5 et seq. [981a28 et seq.]) formulou a célebre tese de que "conhecer é conhecer pelas causas". Nos Analíticos posteriores, 71b9-11, encontramos uma formulação mais completa, abrindo o segundo capítulo do primeiro livro: "Supomos possuir o conhecimento científico incondicional de algo, ao invés de conhecê-lo de modo acidental como conhece o sofista, quando pensamos conhecer a causa de que o fato depende, como a causa desse fato e não de outro, e ainda que o fato não poderia ser outro senão esse [me endechesthai toutallos echein]" (Aristóteles, 2001, p. 111; grifos nossos) ${ }^{1}$. A afirmação parece irrefutável, sendo mesmo considerada "evidente" por Aristóteles (71b12), desde que estejamos dispostos a admitir que tal conhecimento, enquanto mera representação, nada diz da essência do representado como tal, e menos ainda do próprio representar. De fato, conhecer, em sentido estrito, significa reconduzir o fenômeno às suas razões, mas a essência do conhecimento não é aí tematizada; apenas se lhe indica o objeto: as causas e os porquês das coisas, não do conhecer ele mesmo. Irrefutável e correta que seja, a tese permanece incompleta. O seu destino infeliz é bem explicitado por Heidegger, ao indicar o desvio de Aristóteles após se lhe haver desvelado o sentido da filosofia como "ciência" do ente enquanto ente (cf. Heidegger, 2007f, [§ 6, p. 25-26] p. 64-65; 2003, p. 39-44 [§§ 9-10]). Isso porque causas explicam, e explicações, como veremos, servem como tranquilizantes, mas nada se diz acerca do que há por tranquilizar. A tese, portanto, se dirige aos objetos do conhecimento, não à sua essência. Em sua conferência "Que é isto - a filosofia?", constata Heidegger (2000a, p. 33): "Após dois milênios e meio me parece que teria chegado o tempo de considerar o que afinal tem o ser do ente a ver com coisas tais como 'razão' e 'causa'", e então se pergunta: "Em que sentido é pensado o ser para que coisas tais como 'razão' e 'causa' sejam apropriadas para caracterizarem e assumirem o sendo-ser do ente?". Os próprios significados, sempre pressupostos, de "razão" e "causa" são impensados, como observa Heidegger (2000c, p. 107) em outra conferência, a saber, "O fim da filosofia e a tarefa do pensamento":

Enquanto a Ratio e o racional permanecerem duvidosos no que possuem de próprio, fica também sem fundamento falar de irracionalismo. A racionalização técnico-científica que domina a era atual justifica-se, sem

1 Cf. o comentário de Casanova (2003, p. 19) a esta passagem, em que, oferecendo-lhe uma tradução diversa, discute o sentido aristotélico para o termo aitia e a sua ligação com as noções de "fundamento" e "razão suficiente". De nossa parte, chamamos a atenção para o caráter psicológico da tese, uma vez que, embora afirmada com segurança, diz respeito ao modo como representamos a certeza de conhecer, tema central em discussão no presente trabalho. 
dúvida, de maneira cada vez mais surpreendente através de sua inegável eficácia. Mas, tal eficácia nada diz ainda daquilo que primeiro garante a possibilidade do racional e irracional. A eficácia demonstra a retitude da racionalização técnico-científica. Esgota-se, no entanto, o caráter de revelado daquilo que é, na demonstrabilidade? Não tranca a insistência sobre o demonstrável justamente o caminho para aquilo que é?

Se a "perplexidade" (thauma) acompanhada da "dúvida" (aporia), como quer Aristóteles (2002, p. 11 [982b12-18]), e já Platão antes dele no Teeteto (2006, p. 55 [155d]), pode ser apontada como o começo do filosofar, nem por isso se explica a sua origem, ou proveniência ontológica, mas tão-somente o que podemos denominar "disparo psicológico", um fato da consciência. Se é verdade que as coisas não são assim, que o thauma não é apenas uma causa psicológica - é o que defende Heidegger (2000a, p. 37-38), muito provavelmente com razão no que concerne aos gregos -, devemos admitir que há muito impera um grande mal entendido a respeito, como se verifica na história. Indo um pouco mais longe, Descartes proporá que duvidar já é pensar, ao inferir: "Se duvido, penso". Isso deveria significar que o pensamento já é ali quando nos surpreende, não podendo ser causado por algo em nós e, portanto, derivado - em vez disso, já sempre somos no pensar, o que permite que se infira: "Se penso, sou". Acontece, porém, que a dúvida cartesiana, além de permanecer como fato da consciência, é ela mesma inscrita em uma "história da dúvida" na medida em que o mundo posto em questão por Descartes, incluindo aí a própria existência, só pode se converter em objeto do duvidar após um muito longo processo, cujo ápice, atingido na modernidade, coincide com a exigência de provas para a realidade do mundo exterior, do eu, denunciando um desenraizamento cujo sentido abordaremos mais abaixo. Por agora, nos detemos na redução do pensamento à representação, ao conhecimento de causas e porquês. De todo modo, o "disparo psicológico" para o pensamento como representação, em Descartes, não mais se vê acompanhado necessariamente de um humor originário; a perplexidade, a esta altura, decorre da dúvida perante "fatos da vida". Mais e mais o objeto do conhecimento deixa de ser o mundo como tal, sendo substituído por representações de mundo, deixa de ser a realidade, substituída por conceitos.

É pelo esforço empreendido para se libertar de alguma dúvida que alguém se torna filósofo [...]. Mas, o que distingue nisso os verdadeiros filósofos dos falsos é que, nos primeiros, a dúvida nasce em presença da realidade ela mesma; nos segundos, ela nasce simplesmente, por ocasião de uma obra, de um sistema, em presença do que eles se situam. (Schopenhauer, 2004, p. 60-61 [§ 7]). 
Esta consideração não deixa de guardar afinidade com a crítica de Husserl (apud Heidegger, 2000c, p. 100) presente em A filosofia como ciência rigorosa: "Não é das filosofias que deve partir o impulso para a pesquisa, mas das questões e dos problemas". "O chamado 'à questão mesma' dirige-se", explica Heidegger no mesmo lugar, "contra o historicismo que se perde nos debates sobre os pontos de vista da filosofia e na direção dos tipos de visão de mundo filosóficos". Obviamente, o humor originário não está verdadeiramente ausente aí; ele apenas se encobriu. Se, para Heidegger (2000a, p. 37), o thauma não é apenas um começo, mas aquilo mesmo que "carrega a filosofia e impera em seu interior", ou seja, a sua essência, é porque o entende privilegiando-o como pathos, em alemão, Stimmung - nesta condição é a arché da filosofia. Explica Heidegger a seguir:

Traduzimos habitualmente páthos por paixão, turbilhão afetivo. Mas, páthos remonta a páskhein, sofrer, aguentar, suportar, tolerar, deixarse levar por, deixar-se con-vocar por. É ousado, como sempre em tais casos, traduzir páthos por dis-posição, palavra com que procuramos expressar uma tonalidade de humor que nos harmoniza e nos con-voca por um apelo. Devemos, todavia, ousar esta tradução, porque só ela nos impede de representarmos páthos psicologicamente, no sentido da modernidade. Somente se compreendermos páthos como dis-posição (dis-position) podemos também caracterizar melhor o thaumázein, o espanto. No espanto detemo-nos (être en arrêt). É como se retrocedêssemos diante do ente pelo fato de ser e de ser assim e não de outra maneira. O espanto também não se esgota neste retroceder diante do ser do ente, mas no próprio ato de retroceder e manter-se em suspenso é ao mesmo tempo atraído e como que fascinado por aquilo diante do que recua. Assim, o espanto é a dis-posição na qual e para a qual o ser do ente se abre. O espanto é a dis-posição em meio à qual estava garantida para os filósofos gregos a correspondência ao ser do ente.

Tal correspondência significa, para Heidegger (2000a, p. 32), como o homologein heraclítico, co-responder ao Logos, falar como o Logos fala, estar, pois, em acordo (harmonía) com o sóphon - eis em que direção Heidegger compreende o dito nos fragmentos 2 e 50 de Heráclito. Considerando-se o devido relevo dado à disposição da angústia, cabe lembrar as palavras de Kierkegaard (1962): nós a amamos e a odiamos, corremos para ela e dela fugimos. Eis como Heidegger compreende o "começo" da filosofia e, em especial, a possibilidade de sua vigência, bem como aquilo que, estando ameaçado, põe em perigo o pensamento e, assim, o nosso próprio ser em sua propriedade ${ }^{2}$. O co-responder, que

2 Cf. Heidegger, 2007a, p. 30-31: "A ameaça, que pesa sobre o homem, não vem, em primeiro lugar, das máquinas e equipamentos técnicos, cuja ação pode ser 
significa responder-junto-a-um-apelo no homologar, em uma só fala junto ao ser do ente, como que no atendimento do ente, na cura (Sorge) do ente em seu ser, consiste em expressão privilegiada no sentido da distinção com relação a tudo aquilo que entendemos por investigação, que não escuta - insere-se como penetração nas entranhas do objeto, ao mesmo tempo ex-ploratória como movimento violento de arrancar para fora de seu seio o que lhe pertence. (Observemos intempestivamente que plorare, ploratus, em latim, remetem a choro e aflição; daí enfatizamos que, alegoricamente, toda investigação exploratória significaria algo como uma violência aos entes em seu ser). Co-responder significa, antes, uma atitude "respeitosa" e propriamente dedicada em relação ao ente, como a do humilde pastor junto a seu rebanho, tantas vezes evocada por Heidegger na maturidade de sua obra, não sendo à toa que a filosofia tem o amor em sua constituição.
Philosophía é a correspondência propriamente exercida, que fala na medida em que é dócil ao apelo do ser do ente. O corresponder escuta a voz do apelo. O que como voz do ser se dirige a nós dis-põe nosso cor- responder. "Corresponder" significa então: ser dis-posto, être dis-posé, a saber, a partir do ser do ente. Dis-posé significa aqui literalmente: ex-posto, iluminando e com isto entregue ao serviço daquilo que é. $\mathrm{O}$ ente enquanto tal dis-põe de tal maneira o falar que o dizer se harmoniza (accorder) como o ser do ente. O corresponder é, necessariamente e sempre e não apenas ocasionalmente e de vez em quando, um corresponder dis-posto. Ele está numa disposição. E só com base na dis-posição (dis-position) o dizer da correspondência recebe sua pre- cisão, sua vocação3 ${ }^{3}$ (Heidegger, 2000a, p. 36-37).

eventualmente mortífera. A ameaça, propriamente dita, já atingiu a essência do homem. O predomínio da com-posição [Ge-stell] arrasta consigo a possibilidade ameaçadora de se poder vetar ao homem voltar-se para um desencobrimento mais originário e fazer assim a experiência de uma verdade mais inaugural". Id. ibid., p. 34: "A com-posição é o perigo extremo porque justamente ela ameaça trancar o homem na dis-posição, como pretensamente o único modo de desencobrimento. E assim trancado, tenta levá-lo para o perigo de abandonar sua essência de homem livre. Precisamente, neste perigo extremo, vem a lume sua pertença mais íntima. Trata-se da pertença indestrutível ao que lhe concede e outorga. Tudo isso, na suposição de que, da nossa parte, comecemos a pensar, com cuidado, a essência da técnica". Sobre a acepção de "Ge-stell", cf. ibid., p. 23-24. Trata-se, dito brevemente, da essência da técnica como pôr tudo à disposição em um duplo movimento de exploração e produção, ex-posição e pro-posição. No asseguramento da com-posição o ser-no-mundo se encontra ameaçado pelo perigo de encobrimento total de sua liberdade essencial, uma vez que se deixa encravizar e explorar pela técnica.

3 A relação entre "disposição" e "vocação" não é acidental, mas antes explicita a carga semântica de "Stimmung", traduzível não apenas como "disposição", mas como "humor", "tonalidade [afetiva]". Aquilo a que se responde e corresponde na sintonia do humor próprio é a própria voz do ser do ente. Estar na dis-posição significa responder à vocação de nosso próprio ser, dispor-se à tarefa do pensamento, devendo ser a partir daí compreendida a fala originária do fenômeno, o sentido do logos, o apelo da consciência, etc. 
A disposição, conforme nos indica a partícula "dis", sempre remete a uma contrapartida, não uma afetação unilateral, sendo algo existencialmente enraizado e perene, ainda que latente, não algo de casual. Desse modo, não significa que o pathos filosófico tenha se alterado em sua essência, mas sim que se desenraizou a ponto de se encontrar esquecido de sua própria proveniência - disso as "modernas" filosofias são o sintoma, sobretudo as "racionalistas". Não é à toa que esse signo de decadência coincida com o movimento que poderíamos denominar "libertação do pensamento", ou melhor, do "eu penso". Quando duvidar já é pensar, ou seja, quando o pensamento se revela graças à dúvida, embora isso seja verdadeiro enquanto se compreenda pensamento como representação e representação como representação de um querer, um interesse, o pensamento se converte em atividade espiritual autônoma, no sentido de que já sempre se pensa enquanto se é e existe - afinal, a nossa essência é pensar. Se a nossa essência é ser-pensante, o pensamento a nada mais se deve senão ao próprio existir, ou vice-versa, conforme o ponto de vista; o que quer que lhe seja suscitado, como a dúvida, resulta dele mesmo. Já Aristóteles parece considerar o pensamento algo natural, na medida em que diz: "Todos os homens, por natureza, tendem ao saber" (2002, p. 3 [980a21]). Mais categoricamente, Heráclito teria dito que o pensar é comum a todos no fragmento 113 (Pré-socráticos, 1996, p. 99). Mas, apenas nos representamos a nós mesmos como racionais por empregarmos a razão, e essa evidência antropológica nada diz acerca daquilo segundo o que esse emprego se realiza de fato - uma deficiência fatal de quase toda ciência da cultura, à exceção de autores que, como Geertz em seu A interpretação das culturas, percebem a necessidade de se questionar segundo o que, afinal, o homem é um "ser cultural". Tudo que sabemos é que, pensando, já somos racionais. É como dizer que o homem pensa por natureza, não porque "algo mais" o torna disposto a efetivar uma possibilidade da razão. Ao homem, portanto, não é dado não pensar, mas não se esclarece o porquê disso senão atribuindo-lhe uma natureza pensante - ora, tal conclusão já é dada previamente no conceito tradicional de pensamento... O pensamento parece aí já sempre assegurado de si mesmo e por si mesmo, mas apenas parece. Vivemos a carência do pensar, ressaltará Heidegger recorrentemente. Pensar a possibilidade da razão exige uma nova atitude de pensamento, inauguralmente requerida por Heidegger da maneira mais explícita.

Talvez exista um pensamento fora da distinção entre racional e irracional, mais sóbrio ainda do que a técnica apoiada na ciência, mais sóbrio e por isso à parte, sem a eficácia e, contudo, constituindo uma urgente necessidade provinda dele mesmo. Se perguntarmos pela tarefa 
deste pensamento, então será questionado primeiro, não apenas este pensamento, mas também o próprio perguntar por ele. (Heidegger, 2000c, p. 108).

A resposta de Heidegger com relação à origem do pensar é inovadora: que toda compreensão, prévia a toda interpretação e cognição, supõe uma disposição, uma sintonia. É inovadora, dado que, além de mediar humor e cognição pela compreensão e interpretação prévias, não trata o primeiro como mero fenômeno psicológico, conforme já vimos. Tal inovação ainda problematiza dois preconceitos fundamentais da modernidade e de seus herdeiros: a autonomia da razão e, por conseguinte, a possibilidade de uma racionalidade não-ideológica, estritamente técnica e impacial, ou seja, uma racionalidade independente de um prévio horizonte hermenêutico. Por isso mesmo, a história das representações do serlivre se fez necessária ${ }^{4}$.

Muitas vezes e quase por toda parte reina a ideia de que o pensamento que se guia pelo modelo da representação e cálculo puramente lógicos é absolutamente livre de qualquer dis-posição. Mas, também a frieza do cálculo, também a sobriedade prosaica da planificação são sinais de um tipo de dis-posição. Não apenas isto; mesmo a razão que se mantém livre de toda influência das paixões é, enquanto razão, pre-dis-posta para a confiança na evidência lógico-matemática de seus princípios e regras. (Heidegger, 2000a, p. 39; ver nota de Stein a este trecho).

Tal confiança consiste no pretenso remédio para uma angústia inaudita a que já aludimos. O encobrimento da angústia por aparatos metodológicos e um sem-número de doutrinas epistemológicas demonstra o quão antiga é essa decadência no próprio âmbito da filosofia, ou sobretudo aí - ainda que não tenha sido Aristóteles a sistematizar o seu próprio pensamento, foi ele a primeiramente produzir algo como um Organon, seja atendendo a necessidades circunstanciais, seja a necessidades oriundas de seu próprio projeto científico. Com o tempo, o pensamento segundo causas domina, no mesmo interesse de asseguramento, o âmbito do voluntário. Por um desvio já inevitável, a vontade já começa a ser pensada, desde as suas raízes na doutrina cristã do livre-arbítrio, como causa das ações e, portanto, à luz da obscura noção de domínio-de-si. Ser livre é ser causa de si mesmo. Na contramão dessa via, Nietzsche e Schopenhauer empreenderão a sua crítica à modernidade cristã, já tendo sido pressentida por ambos a exigência, também posta por Heidegger, de elucidação do que significam "razão" e "causa".

4 Esta história é sumariamente realizada em nossa tese de doutoramento Liberdade e negação da vontade: análise do ser-livre como representação e na angústia, capítulo 4 , "O homo amphibios". 
Sempre se acreditou saber o que é uma causa: mas de onde retiramos nosso saber, mais exatamente, nossa crença neste saber? ${ }^{5}$ [...] Acreditávamos em nós mesmos como tendo uma participação causal no ato de vontade; pensávamos surpreender aí no mínimo a causalidade em meio ao ato. Do mesmo modo, não se duvidava de que todos os antecedentia de uma ação, suas causas, pudessem ser buscadas na consciência. E que, buscando-as aí, se as reencontraria - como "motivos". Do contrário, não se teria sido nem livre para a ação, nem responsável por ela. [...] O que segue daí? Não há de modo algum nenhuma causa espiritual! (Nietzsche, 2000, p. 43-44 ["Os quatro grandes erros", §3]).

Nietzsche, como Schopenhauer, pode-se dizer com segurança, nega a vontade enquanto causalidade, reconhecendo-lhe o caráter de uma dolorosa confluência de forças, como sendo ela mesma puramente afirmativa; por isso mesmo, a dor, como a ausência de sentido, é, aqui, o positivo. A diferença crucial entre ambos é que o segundo o lamenta. Seria a partir dessa dolorosa experiência interna da ausência de sentido que a tranquilização pelas representações causais é transposta para o domínio da natureza, já separada daquele da consciência.

As representações, que produziram uma certa disposição, foram mal compreendidas e transformadas em suas causas. ${ }^{6}$ [...] queremos um motivo para nos sentirmos dispostos de tal ou tal modo, para nos sentirmos mal ou bem dispostos. Nunca é suficiente para nós constatar o fato de nos sentirmos de tal ou tal modo: só aceitamos esse fato - só tomamos consciência dele - quando lhe entregamos um tipo de motivação. - A recordação que, sem nosso saber, entra em atividade em tais casos, traz à tona estados anteriores do mesmo tipo e interpretações causais que aí estão articuladas - não sua causalidade. Decerto, a crença em que as representações, os processos de consciência acompanhantes, tinham sido as causas, também é trazida à tona pela recordação. (Nietzsche, 2000, p. 45-46 ["Os quatro grandes erros", § 4]).

Eis o que, segundo Nietzsche (2000, p. 46 ["Os quatro grandes erros", §5]), nos dá "um sentimento de potência", de asseguramento, um solo, a possibilidade de, pela representação de causas, encontrarmos uma razão para o que fazemos e, ainda, para o que somos - nessa pretensa segurança fundamos todo o nosso saber. Assim nos tranquilizamos, aliviamos e

5 Convém observar que, de acordo com a citação inicial de Aristóteles, o conhecimento pelas causas é um saber que acreditamos ter. Além disso, a pergunta de Nietzsche é precisamente aquela cuja resposta afirmamos de início como ausente.

6 O primeiro ensaio dessa genealogia consiste no fragmento "Sobre verdade e mentira", de 1873, onde vemos como Nietzsche (2007) explica como o último na ordem do conhecimento, ou seja, a ideia, o conceito, se converte no primeiro na ordem da ontologia, de Platão a Hegel. O restante da passagem aqui citada remete à crítica humeana da causalidade. 
satisfazemos em face do perigo, da inquietude e da preocupação que o desconhecido ordinariamente nos proporciona exceto quando remetido a algo de conhecido, ainda que tal conhecimento seja uma ficção nossa, e daí também provém a ordinária recusa de tudo que se mostra estranho, de toda "novidade", a que nossa primeira resposta tende a ser precisamente a recusa. Nisso consiste toda recusa, todo "não!" reativo, como "primeiro instinto [...] para a eliminação desses estados penosos". Prossegue Nietzsche:

Primeiro princípio: qualquer explicação é melhor do que explicação nenhuma. Porque no fundo se trata apenas de querer livrar-se de representações angustiantes, não se considera com a exatidão necessária os meios de produzir um tal movimento. A primeira representação, com a qual o desconhecido se explica como conhecido, faz tão bem que se a "toma por verdadeira". [...] O impulso causal está assim condicionado e provocado pelo sentimento de medo. Se houver alguma possibilidade, o "por quê?" não deve tanto entregar a causa em virtude dela mesma, mas entregar sim um tipo de causa. - Uma causa que aquiete, que liberte e que torne mais leve. [...] uma espécie escolhida e privilegiada de explicações, que tragam consigo o mais rápida e frequentemente possível a extinção do sentimento do estranho, do novo, do não-vivenciado: as explicações mais usuais. [...] O banqueiro pensa imediatamente no "negócio", o cristão no "pecado", a moça em seu amor.

Devemos, contudo, questionar se isso tudo reside tanto na psicologia quanto se nos mostra pertencer à ontologia. Ou seja, em que medida já não será sempre esse "comportamento" um fenômeno subjetivo enraizado na existência, em nosso modo de ser. É então de causar surpresa o fato de Nietzsche, enquanto crítico do sujeito, fazer-se psicólogo - sinal de que, enquanto crítico da metafísica, encurralara-se entre o sujeito e o ser sem poder dar um passo em qualquer direção, razão pela qual a sua lucidez divide espaço com a obscuridade, ambas resguardadas em sua poesia e por ela "justificadas". De todo modo, ainda se vê em que medida a invenção do Inconsciente, por Freud, criando assim o paradigma da Psicanálise, faz perder de vista e mesmo reverte o movimento crítico empreendido por Schopenhauer e Nietzsche na medida em que, em última análise, o Inconsciente não é nada mais do que um novo nome para uma causa oculta. A estranheza desta criatura - o Inconsciente - divide espaço com a estranheza de seu propósito - uma explicabilidade científica. Freud representa o exemplo cabal de que a descoberta de uma causa supõe já uma investigação que pergunta por causas; a causa é pressuposta e identificada a uma entidade (o Inconsciente, nesse caso) de modo a meramente substituir outra, o espírito; questionando o dualismo corpoespírito, Freud põe a perder a sua pretendida superação da metafísica e procura fazer do imponderável um objeto da ciência capaz de expli- 
car as pulsões, a vontade, a angústia, objetos em si mesmos vagos e não-científicos. "A ciência sempre se depara e se encontra, apenas, com o que seu modo de representação, previamente, lhe permite e lhe deixa, como objeto possível" (Heidegger, 2007c, p. 148). Ainda: "Toda prova vem depois de se tomar como base certas pressuposições. Tudo se deixa provar depois de assumidas as pressuposições. Prestar atenção, porém, isso só podemos em relação a poucas coisas" (Heidegger, 2007d, p. 173).

Acontece, porém, que a liberdade nada tem a ver com causalidade e, conforme enfatiza Heidegger (2007a, p. 28), a sua essência "não pertence originariamente à vontade e nem tampouco à causalidade do querer humano". Como a liberdade da vontade nada tem a ver com potência ou autodomínio, mas com a possibilidade de querer, é mais correto dizer que a vontade pertence à liberdade; sendo-livre, é possível ao homem admitir-se como sendo-vontade, relação essa invertida segundo a perspectiva de suas representações. Sendo-livre, o homem encontra-se originariamente situado na abertura do poder-ser, de cujo nada foge para junto dos entes aos quais se liga mediante o interesse; como é a vontade a reger tal ligação, uma vez pensada como causa, a mera representação da liberdade como possibilidade de escolha é interpretada como efeito do fato dado de sermos-vontade. Todo problema "moral" é reduzido a problema do "conhecimento"; consciência do moral e consciência do verdadeiro são uma só coisa. Daí que "razão" e "motivo" convergem na noção de "fundamento", sendo no texto "Sobre a essência do fundamento" que Heidegger (2000d) desenvolve da maneira mais completa e compreensiva a tese, contrária à da tradição, da liberdade (transcendência) como origem do fundamento em geral, como abismo do Dasein, a tal ponto que um comentário pormenorizado, no presente momento, terminaria nos desviando do propósito deste trabalho ${ }^{7}$.

Retomando então o que dizíamos há pouco, segundo Heidegger, o próprio representar supõe uma compreensão prévia, enraizada em nosso próprio modo de ser, e tal compreensão, por sua vez, deve se radicar em alguma disposição, ou humor (Stimmung), o que, todavia, parece privar o pathos filosófico do que lhe é, segundo a tradição, o mais caro, a saber, a liberdade, a ociosidade, a iniciativa, posto que sempre se pensou (representou) o pensamento como uma livre atividade do espírito independente de nosso modo de ser, mas antes como algo necessitado por nossa natureza racional. Segundo a tradição, em outros termos, o pensar humano não é apenas uma propriedade, uma possibilidade que, como tal, pode estar ausente, mas uma necessidade.

Para um tratamento pormenorizado das questões indicadas neste parágrafo, ver nossa tese de doutoramento, referida em nota acima. 
Um dos aspectos mais objetáveis da enfatização da sintonia é que ela nos obriga a renunciar a grande parte da autonomia do pensamento. Este agora parece ser meramente uma articulação do que quer que seja dado no humor e uma reação a isso. (Svendsen, 2006, p. 127).

Por sua vez, que o pensamento propriamente dito seja convocado por algo como um humor (de surpresa, de perplexidade, de angústia, de tédio), isso consiste em uma afirmação das mais antigas e características, ainda que, como vimos, tenha tido a sua verdade crescentemente encoberta. Contudo, como também foi indicado, não pode se tratar apenas de uma "reação" como um efeito que se segue a uma causa, um disparo psicológico mediante uma adversidade casual. Não se deve entender a convocação do pensar pelo humor como um efeito que se segue a uma causa, pois estaríamos nos referindo novamente a um mero sentimento subjetivo, a um comportamento psicológico com lugar em uma "interioridade", ou representação de si mesmo como algo - daí mesmo que o problema do conhecimento e ainda o problema do ser se viram enredados no subjetivismo. Trata-se antes de uma espécie de ambiência propiciadora de um liberar que contempla (theoria) - tal ambiência, deve-se esclarecer, não é nem o ambiente externo dado, nem o nosso sentimento interno de estar-ambientado, mas a sua condição. Como diz Heidegger (2000a, p. 37),

Enquanto dis-posta e con-vocada, a correspondência é essencialmente uma dis-posição. Por isso o nosso comportamento é cada vez disposto desta ou daquela maneira. A dis-posição não é um concerto de sentimentos que emergem casualmente, que apenas acompanham a correspondência. Se caracterizamos a filosofia como a correspondência dis-posta, não-posta, não é absolutamente intenção nossa entregar o pensamento às mudanças fortuitas e vacilações de estados de ânimo.

Assim chegamos ao já indicado problema da dúvida: se a dúvida move as nossas representações, tal movimento se dirige a certezas. Desse modo, o fato de todo asseguramento sempre se pautar em saberes, e esses se constituírem no âmbito de representações interessadas, como que exige de nós uma atenção especial ao próprio pensamento em um duplo sentido: no de questionar o humor fundamental que nos situa na precisão de asseguramento pelo saber e, inversamente, no de questionar o caráter do saber assegurador a fim de identificar adequadamente o humor que o exige, que é a ele inerente. Por essa razão, o tema da angústia não pode nem deve ser separado do tema da representação, ou, caso se prefira, do conhecimento em sentido lato. Com isso, adicionalmente, a liberdade para pensar, tematizada a partir da disposição fundamental 
da angústia, deixa de ser investigada à luz do obscuro, vago e mesmo vazio conceito de "autonomia do espírito". Se a ligação entre um e outro - humor e saber - é inerente ao problema do sentido da existência, como defendemos ser o caso, cabe-nos explicitá-la. Como poucos comentadores, Svendsen (2006, p. 123) aponta para isso:

Estar num determinado humor não é meramente uma determinação ontológica do homem, pois constitui também uma condição epistêmica para as diversas maneiras pelas quais objetos podem transmitir significado. Um humor torna algumas experiências possíveis, outras impossíveis. Condiciona o modo como o mundo - portanto também todos os objetos e eventos - aparece para nós.

Tal condicionamento, no entanto, conforme já indicado, não deve ser interpretado à luz de uma ordenação causal, mas no sentido de uma condição ontológica, uma condição de ser que é inerente ao ato percepcional/representacional. Assim prossegue Svendsen (2006, p. 123-124):

Acredito que é ligeiramente enganoso situar o humor como anterior à descoberta dos objetos particulares, pois ele próprio é dado com a cognição desses objetos. Ao mesmo tempo, é claro que o humor é essencial para o modo como os objetos são percebidos. Ele parece ser anterior à percepção por sua conexão com a faticidade, como um estarno-mundo prévio, mas essa faticidade é revelada simultaneamente com a experiência dos objetos particulares. Há uma certa prioridade do humor, no entanto, uma vez que a cognição pressupõe um interesse que pode lhe conferir certa direção. O humor forma uma moldura básica para o entendimento e a experiência. [...]

[...] O humor é uma condição para a possibilidade do conhecimento, abrindo o mundo como um todo. [...] Experiências tornam-se possíveis em virtude de humores que lhe são adequados".

Portanto, se uma analítica existencial dos humores vem elucidar o sentido íntimo do interesse ou da intencionalidade determinante da percepção e, assim, da própria experiência, pois que o próprio aparecer dos fenômenos já sempre se encontra sintonizado em uma disposição, em sentido inverso, uma crítica das representações da razão e do entendimento somente se completa enquanto orientada para o humor fundamental de que são o sintoma e cuja sintonia forma a consciência. É segundo essa proposta que compreendemos uma certa complementaridade entre os projetos filosóficos de Heidegger e Schopenhauer, independentemente das inúmeras e inquestionáveis divergências de princípio, que não deixam de ter razões contextuais. 
Que as nossas possibilidades de experiência se abrem ou se fecham cotidianamente por humores é algo tão evidente que sequer são requeridos exemplos, a não ser por equívocos quanto ao que se pretende dizer com "experiência". É claro de não se trata aí de experiências sofridas, coisas que nos ocorrem ao acaso ou pela ação de outrem e que, por haverem nos acontecido, nos acometido, passam a "fazer parte da experiência", mais uma dentre tantas "coisas a nosso respeito". Trata-se, em vez disso, de estar ou não disposto a algo. Os humores, repetimos, dizem respeito antes de tudo a possibilidades; possibilidades são sempre "minhas". Mesmo no sentido usual de estar ou não propenso a isso ou àquilo, humores, disposições, sempre remetem ao possível. A diferença entre um humor própria ou impropriamente compreendido se reduz a isso: nesse último caso, trata-se de possibilidades de fato, representáveis - aqui, o humor, como sentimento acerca de algo determinado, dirige a experiência à luz dos interesses. No primeiro, trata-se do possível como tal, ou seja, a possibilidade de ser este que sou - aqui, ao contrário, o humor dispõe o ser-livre perante si mesmo, em sua propriedade e "pessoalidade". A disposição de humor não é uma causa, uma razão ou um fato que simplesmente ocorre antes, mas aquilo que, em se dando junto, possibilita o próprio experimentar em sua imediatidade. O que ocorre "a mim" ocorre necessariamente, por alguma fatalidade ou pela ação de outro; no entanto, é minha disposição - seja em sentido próprio ou impróprio - que, por assim dizer, "dará o tom" da repercussão da ocorrência "em mim". Isso significa que não estamos tratando de coisas que se opõem, mas que confluem e são indissociáveis. Se é verdade que, na decadência cotidiana, tal repercussão tende a ser fortemente ditada por contextualidades impessoais, em última instância, é segundo o meu caráter, a minha singularidade, o meu si mesmo próprio, que me dispõe a ser mais ou menos suscetível a essa ou àquela "influência" do impessoal. É daí mesmo que provém toda querela acerca da ideologia, que afeta uns e outros diferenciadamente. Essas questões, todavia, exigem um estudo à parte.

Com relação à precedência dos humores no que toca às possibilidades de conhecimento - a nossa questão atual -, se ainda é clara no que concerne ao que desejo ou não conhecer, o que me interessa ou não ditando ordinariamente a minha dedicação técnica a saberes e informações, tal precedência parece muitíssimo pouco pensada com relação ao próprio conhecer em geral! Dito de outro modo, é muito pouco discutido o papel dos humores no fundo do próprio interesse pelo saber - que, defendemos, é um interesse, não uma tendência natural ${ }^{8}$-, do próprio impulso original

A tese, formulada desde Aristóteles, de que o impulso para o saber é uma tendência natural do homem, como bem estuda a antropologia cultural, trouxe mais malefícios do que benefícios. Exemplo claro disso é a recorrente perseguição e intolerância sofrida por 
para o filosofar, no fundo mesmo de toda religião, de toda arte, de toda metafísica. É essa a problemática cujo encobrimento apontamos há pouco.

Dito de outro modo, a título de exemplo, estamos habituados a repetir, como coro impotente de uma tragédia, que a filosofia nascera, e nasce a cada vez, mediante a perplexidade, ou mais enfaticamente, o thauma, o maravilhamento, ou a estupefação, o espanto. Antes mesmo da célebre fórmula de Aristóteles, já encontrável em Platão, a ironia socrática não fazia mais que simular esse humor diante da grosseira pretensão de seus intelocutores que se diziam sábios, o que ordinariamente se mostrava improfícuo, uma vez que esses sequer percebiam a sua própria inconsistência. Ensina-se isso! Isso é repetido incansavelmente! Contudo, ninguém antes de Heidegger perguntou-se adequadamente de onde, afinal, provém a tal surpresa em face do não-saber. Popper, por exemplo, antecipou uma excelente resposta: a frustração de uma dada expectativa. Segundo Popper, todo conhecimento se move segundo um horizonte de expectativas. Esse componente do pensamento popperiano, ainda que não declaradamente, remonta a Hegel e à sua dialética da progressão das verdades mediante a contradição da tese pela antítese, na contínua busca da síntese pelo Espírito. Todavia - eis a nossa questão -, como afinal se contitui tal horizonte? Não é pela experiência, afirma com veemência o próprio Popper contra Hume... Aprendemos a caminhar olhando para o chão, a fim de não tropeçarmos, uma vez que tropeçamos e caímos - tropeçar e cair são possibilidades de fato. Isto nos dá a experiência: fatos, não possibilidades - a possibilidade da queda é imaginada graças ao fato de se ter caído alguma vez. Antes do tropeço, a nossa expectativa era a de um caminho regular, sem perigo - imprevistos são, por definição, impossíveis de se prever; imprevisto é sempre o imprevisível. A experiência não nos ensina positivamente senão o erro ${ }^{9}$, o qual nos empenhamos cada vez mais em evitar.

Mas, aprofundando o questionamento, de onde provém o preconceito segundo o qual não há nada a se questionar no fato de sempre acreditarmos

aqueles que, quando não demonstram desinteresse pela ciência e tradição cultural das grandes civilizações ocidentais, simplesmente advogam compreensões de "saber" muito distintas e, por isso, incompreensíveis para nós. Nesse sentido, as guerras religiosas mais arcaicas não diferem das atuais atrocidades cometidas em nome da universalização de regimes políticos e sistemas econômicos calcados no "progresso do saber".

9 Vale observar que a base da doutrina popperiana da falseabilidade já é antecipada por Schopenhauer, bem como a crítica à doutrina humeana de que a causalidade é inferida da experiência. No primeiro caso, Schopenhauer já advoga o modus tollens, o método hipotético-dedutivo e remete ao conceito aristotélico de "apagoge"; no segundo, como Popper, segue a crítica kantiana (cf. Schopenhauer, 2004, p. 115-118/789/805-806 [§15/cap. IX/XII]). A propósito, a despeito de seu mérito no contexto da refutação dos pressupostos positivistas, Popper não traz novidades a esse respeito, uma vez que a sua doutrina da falseabilidade pode ser inferida imediatamente das leis fundamentais 
que, em princípio, o mundo é confiável, que podemos sair andando sem pedras no caminho? Não será que já sempre escapamos originariamente dessa e de qualquer ameaça, que já sempre somos movidos por uma busca e precisão originárias de familiaridade, evitando a todo custo nos situarmos em um mundo estranho no qual devemos tomar precauções antes de qualquer movimento e decisão? Não terá essa confiança a mesma origem de nossas ocupações preventivas? Se, na representação comum, ser livre significa ir e vir sem restrições, como suportar a possibilidade de se ver obrigado a tomar um caminho distinto do planejado, talvez oposto, talvez mesmo obrigado a desistir do percurso? Popper sequer se pergunta sobre isso, interessado que está na vantagem da tese para explicar o progresso das ciências.

De volta à questão dos humores, não terá sido pelo mero desejo ou mesmo pela mera necessidade de emprego de uma faculdade até então ociosa que o homem, repentina ou gradualmente, pôs-se a pensar? Como indicado acima, Heidegger rejeita essa possibilidade em sua conferência "Que é isto - a filosofia?". Tanto menos devemos crer que a metafísica seja fruto de um mero exercício de abstrações. A nosso ver, Schopenhauer dera um largo passo, ao distinguir os dois tipos de "espanto" (Verwunderung) que, respectivamente, movem as ciências particulares e a metafísica. O cientista se admira e inicia as suas investigações em torno daquilo que ocorre de excepcional; o filósofo, em torno daquilo que há de mais comum, mais habitual (Schopenhauer, 2004, p. 852 [cap. XVII]). De acordo com Husserl ([s.d.], p. 39 et seq. [p. 17 et seq.]), na primeira lição de seu curso sobre $A$ ideia de fenomenologia, também a atitude filosófica é radicalmente distinta por princípio da atitude natural, própria tanto às ciências particulares quanto ao senso comum, e nisso ele será seguido por Heidegger (2002) na "Parte Preparatória" do curso "Que é uma coisa?". É notável que até animais manifestem surpresa diante do excepcional, mas apenas ao homem é dado admirar-se do habitual. Como se vê, apenas de modo derivado a diferença específica do homem é ser racional, na medida em que a racionalidade por si só, mesmo naquilo que mais a torna manifesta,

da implicação lógica. A sua importância na história da filosofia da ciência se evidencia justamente pela incompreensão ou má vontade de que foi vítima da parte de seus adversários, levando-o a uma imensa profusão de conferências e artigos em defesa de seu método, que, de fato, é o único válido universalmente. As novidades trazidas por Popper são maiores no âmbito da articulação entre filosofia da ciência e filosofia política e da sua concepção de progresso - sempre manifestando a sua orientação liberal -, sendo ainda de destaque a doutrina do "mundo objetivo da ciência". De resto, Popper traz à luz a surdez daqueles que apostam na possibilidade de demonstração direta da verdade, supondo erroneamente que a ciência natural é diferente da metafísica a esse respeito. O erro desses, mostra Popper, consiste em não perceberem que somente se pode chegar à verdade por vias indiretas. 
como nas grandes descobertas, não garante ao homem a sua singularidade na natureza, pois a razão mesma é posta em movimento por algo que a antecede. Não é por outra razão que a filosofia trata do geral, não do particular, buscando a universalidade e não a especialização, à exceção da filosofia acadêmica dos últimos tempos, que não faz mais do que acompanhar um movimento de destrinchamento universal que há muito já a aprisiona, ultrapassa, arrasta, empobrece - ironia do destino que a própria "filosofia" haja produzido o seu impiedoso, impessoal e desdenhoso algoz. "Cavar entranhas" não exprime a dignidade humana... Uma forma de parafrasear de modo mais contundente a distinção schopenhaueriana, em certa medida seguida por Husserl e Heidegger, é dizer que, como sempre foi sabido na mesma proporção que pouco reconhecido, homens excepcionais se dedicam ao ordinário, enquanto homens ordinários se dedicam e rendem toda a sua atenção, entregam as suas próprias vidas ao excepcional, e mesmo ao incrível, ao sobrenatural - curioso perceber, maldoso dizer, que, ironicamente, sejam esses últimos os mais propensos à mera reprodução das ideias, ao preconceito, denunciando assim, para os poucos que podem ver, a medianidade de seu espírito. O caso de o homem compreender-se como ser vivo, ou seja, a partir de sua animalidade, não deixa de ser sintoma de penúria existencial e, portanto, de pensamento ${ }^{10}$.

Nesses termos, é simples compreender por que Heidegger, em sua ontologia fundamental, no intuito de recolocar a mais antiga e central questão da metafísica ocidental, parte da cotidianidade, não entendida como um agregado de fatos, mas como a ambiência ordinária em que já sempre somos, perscrutando em um movimento leve, porém denso e espiralado, em um crescendo, o modo de ser da familiaridade com o mundo que habitamos, até o fundo segundo o qual o mesmo se constitui. Daí que o pensamento de Heidegger pensa o ser-homem privilegiadamente, e com ele o próprio filosofar em seu pathos, a partir dos humores, chegando ao humor que nos abre os problemas fundamentais da metafísica. Pensar os humores, as Stimmungen, é justamente pensar o que há de mais geral e comum ao ser-homem em seu ser-livre essencial, mas não segundo causas e determinações que constituem a forma contínua de nossas percepções do real - não é à toa que o real se converta em problema. Encontrar o pathos filosófico na angústia, no tédio, na "certeza" e no saber acerca do

10 Embora a classificação do homem como "animal" provenha dos gregos, Heidegger argumenta que zoon remetia a uma experiência completamente distinta. Sobre isso, cf., por exemplo, o texto de "Aletheia (Heráclito, fragmento 16)" (Heidegger, 2007e, p. 242-243). Ademais, o sentido de "animal" é praticamente perdido para nós - de início, indicava o "ser vivo em geral" (zoon), imediatamente movido por si mesmo mediante uma força interna a que se convencionou chamar "alma" (anima), donde temos "ser vivo" ou "vivente" e "ser animado" ou "animal" como termos intercambiáveis. 
morrer, naquilo que Heidegger tem Schopenhauer e Kierkegaard como precursores, longe de significar um olhar sombrio sobre a vida significa retornar à própria origem do pensar. Pensar de tal maneira originário e tão filosoficamente quanto possível, não apenas preenchendo o requisito do mais ordinário à existência, mas também, e sobretudo, apelando para que se pense demoradamente o que, justamente por ser tão comum, tão pouco se pensa e tão raramente se sente. Nesse sentido, o caráter não utilitário da filosofia e a raridade dos autênticos filósofos se nos mostram como constatações derivadas, as quais apenas por distorções do espírito hão de se converter em preconceito.

Como diz Heidegger (2002, p. 14 et passim), nada se começa com a filosofia. A afirmação é ilustrada pela lembrança da antiga anedota sobre a queda de Tales em um poço, enquanto contemplava as estrelas - que estão sempre ali há milênios -, suscitando o riso da serva que não compreendia como alguém que lançava o olhar tão longe não via o que estava sob o seu nariz. (O budismo tem um dito paralelo, cujo conteúdo é algo como: o mestre aponta para o alto; enquanto o sábio olha para a lua, o tolo olha para o dedo. Um animal se comportaria exatamente como o tolo). Com efeito, trata-se de uma inestimável passagem para ser lida por quem queira saber o que significa filosofar, o que Tales significa para o Ocidente - certamente mais do que se depreende da tese segundo a qual a água é o princípio de todas as coisas na natureza, justamente a tese pela qual alguns cientistas, implícita ou explicitamente, lhe rendem homenagem - e diante da qual aquele que se ri denuncia-se a si mesmo como um espírito escravo. Apropriadamente, no entanto, a anedota por si só nada diz do que move o filosofar, do que pusera em certa direção e não em outra qualquer o olhar de Tales. A sua serventia não traduz mais do que o caráter não utilitário da filosofia, e mesmo o comentário de Heidegger, por apropriado que seja, naquele momento, não vai além disso. A questão a ser respondida, e Heidegger o faz alhures, mesmo se não expressamente, é: por que, afinal, Tales olhava para o alto, não para baixo? Por que o que lhe causava espanto era a astronomia, não o caminho que percorria e já deveria ter percorrido tantas vezes? Tal pergunta não se responde apenas dizendo que ele pretendia fundar uma nova ciência - tal interpretação soa bastante anacrônica -, ou que estivesse preocupado com a importância de suas descobertas, tampouco que a física matemática seja uma ciência dotada de valor em si mesma. Não podemos tomar o efeito pela causa nem buscar respostas fáceis fundadas na areia movediça dos preconceitos. O que, afinal, lhe chamou a atenção nos corpos celestes? Ninguém jamais saberá, mas isso, no entanto, não impede que se pense o que, em geral, nos faz olhar para aquilo que está sempre ali, mas como se fosse algo inusitadamente novo, digno 
de nossa admiração. O que havia no olhar de Tales, ausente no olhar da escrava, será resultado de instrução, posição social ou qualquer coisa de acidental? Arriscamos dizer que não, e Platão certamente também o diria a julgar pelo Mênon. Heidegger responde negativamente, no curso sobre "Os conceitos fundamentais da metafísica". De nossa parte, diríamos antes que a possibilidade de pensar o não pensado se lhe abriu de uma determinada maneira, por isso merecendo o título de "pai da filosofia", não por eleger outro princípio para o mundo que não o divino, como já se defendeu no interesse da infeliz oposição entre mito e filosofia.

A resposta de Heidegger é que o humor abre o mundo como mundo, e assim está na origem do pensar autêntico ou próprio. Abrir o mundo como mundo e, ao mesmo tempo, promover uma perplexidade significa justamente a ruptura, trazida no humor, com a familiaridade cotidiana do mundo; o que até então parecia assegurado, agora se encontra suspenso e sem solo. Mas, como dissemos, Schopenhauer e Kierkegaard são os seus precursores. O que Schopenhauer encontrava de mais comum e próprio à vida era o sofrimento, a dor moral, o conhecimento da morte, razão pela qual os seus comentadores facilmente o qualificam como pessimista. É então desses sentimentos tão universais que Schopenhauer extrairá o seu fio condutor para a elucidação do impulso para o pensar filosófico. É precisamente no conhecimento da morte pelo homem que Schopenhauer encontra a origem do que designa "necessidade metafísica do homem", ou seja, o originário impulso humano para pensar a essência do mundo, aquilo mediante o que o mundo das representações, de conhecido, tornase despropositado, vazio e insubstancial como uma miragem.

É no §8 de O mundo como vontade e representação que Schopenhauer (2004, p. 67), pela primeira vez nessa obra, refere-se à "pré-ciência da morte" como "o princípio das filosofias e das religiões". Diferente dos animais, o homem é dotado do que Schopenhauer denomina "previdência" (Besonnenheit), vinculada à razão, ou faculdade para a produção de abstrações. Trata-se de uma consciência capaz de fazer emergir uma angústia a priori que somente se encontra no ente cuja vida se volta para passado e futuro, não para o instante. Paralelamente, para Kierkegaard (1979, p. 197), o homem é superior ao animal por "ser suscetível de desesperar". "Se o homem fosse apenas um animal como os outros, ele viveria em um mundo não-problemático. O animal cujo 'olhar calmo' exprime 'a sabedoria da natureza' [Schopenhauer, 2004, p. 851] vive em um mundo sem assombro. É o assombro que faz do homem 'um animal metafísico'" (Brum, 1998, p. 76) O tema retornará no último capítulo dos Suplementos ao primeiro livro de $O$ mundo como vontade e representação, acima citado por Brum, "Sobre a necessidade metafísica da humanidade", que tem início com as seguintes palavras: 
À exceção do homem, nenhum ente se espanta de sua própria existência; é para todos uma coisa tão natural, que eles sequer a notam. [...] Seu espanto é tão mais sério que, pela primeira vez, [o querer viver em sua objetivação] se aproxima da morte com plena consciência, e com a limitação de toda existência [der Endlichkeit alles Daseyns] também a inutilidade de todo esforço se torna para ele mais ou menos evidente. (Schopenhauer, 2004, p. 851).

Por essa razão, o espanto filosófico é, para Schopenhauer (2004, p. 865), "no fundo uma estupefação dolorosa". "O sofrimento é o a priori de toda filosofia do tipo existencial como a de Nietzsche ou a de Schopenhauer. O ser que se interroga, que pensa o mundo como assombro, é um ser que sente a sua fragilidade, a sua ausência de necessidade, o seu caráter contingente" (Brum, 1998, p. 77). Mas, como diz o próprio Nietzsche (2000, p. 34 ["Moral como contranatureza", § 1]), "atacar os sofrimentos na raiz é o mesmo que atacar a vida na raiz", de maneira que tal ataque se configura como pathos niilista. Por outro lado, ir até essa raiz permite encontrar a angústia originária em face do caráter absurdo de toda existência. É pelo que a angústia faz emergir, o "nada" (nihil), que a metafísica pode pertencer à natureza humana mesmo para Heidegger (2000b, p. 62-63), em um sentido, contudo, muito diverso da interpretação tradicional acerca do caráter "natural" do pensamento. Essa pertinência da metafísica à natureza humana se dá pois metafísica, para Heidegger, significa o ultrapassar o ente, que acontece na essência do Dasein graças à sua possibilidade de suspensão no nada. "Somente porque o nada está manifesto nas raízes do ser-aí pode sobrevir-nos a absoluta estranheza do ente. Somente quando a estranheza do ente nos acossa, desperta e atrai ele a admiração. Somente baseado na admiração - quer dizer, fundado na revelação do nada - surge o 'porquê'". Diferente então de Aristóteles, Heidegger coloca como condição para o nosso "destino de pesquisador" a possibilidade de "perguntar, de maneira determinada, pelas razões e fundamentar", que por sua vez remete à possibilidade do "porquê". A metafísica "não é uma disciplina da filosofia 'acadêmica', nem um campo de ideias arbitrariamente excogitadas. A metafísica é o acontecimento essencial no âmbito do ser-aí. Ela é o próprio ser-aí". A metafísica é o ser-aí, e o ser-aí é a ultrapassagem, é transcendência, é liberdade ${ }^{11}$. À liberdade do Dasein, admite o próprio Heidegger, pertence também uma vontade:

11 Isto não contradiz o fato de a metafísica ser também uma fatalidade pela qual "a humanidade vê-se fadada a assegurar-se no ente" (Heidegger, 2007b, p. 67 [VIII]), desde que compreendamos a "fatalidade" em Heidegger. Afinal, a sua condição existencial já foi sempre decidida no âmbito do projeto de ser-no-mundo, segundo a sua liberdade essencial. Sendo sempre o fato de sua existência já decidida, e tendo o filosofar a sua origem em disposições próprias, é próprio ao Dasein ser o fato da metafísica. 
O ser-aí só pode [...] ser para si como para si mesmo, se "se" ultrapassa no em-vista-de. A ultrapassagem com o caráter de em-vista-de somente acontece numa "vontade", que como tal se projeta sobre possibilidades de si mesmo. Esta vontade, que essencialmente sobre-(pro-)jeta e por isso projeta ao ser-aí o em-vista-de-si-mesmo, não pode, por conseguinte, ser um determinado querer, um "ato de vontade", à diferença de outros comportamentos (por exemplo, representar, julgar, alegrar-se). Todos os comportamentos radicam na transcendência. Aquela vontade, porém, deve "formar", como ultrapassagem nela, o próprio em-vista-de. Aquilo, entretanto, que, segundo sua essência, antecipa projetando algo tal como em-vista-de em geral e não o produz também como eventual resultado de um esforço, é o que chamamos liberdade. A ultrapassagem para o mundo é a própria liberdade. (Heidegger, 2000d, p. 140).

Desse modo, é à possibilidade e não à necessidade que devemos a nossa "tendência ao saber" e ao nada, não a uma ordem estabelecida preexistente que devemos o pathos filosófico. A estranheza que em nós emerge provém de nossa essência, não de nossa ignorância, assim como é nossa essência mesma que nos convoca a pensar, não um ócio meramente circunstancial, tampouco um interesse determinado. Não há algo como um puro salto do desinteresse ao interesse por algo como "querer saber", mas uma possibilidade posta por nada que inadvertidamente nos convoca a pensar e, no pensamento, tornar desvelado o limite entre saber e não-saber. Isso significa: a abertura para nada é mais originária que toda mera ignorância; antes da abertura, nada se ignora, sendo precisamente segundo um fechamento existencial que se deixa de dar atenção ao que já sempre está ali diante de nós como horizonte de sentido segundo o qual já sempre nos movemos. Quanto a isso, fácil é observar que o ócio não é condição suficiente para o despertar do pensamento, tampouco, talvez, condição necessária desde que compreendamos que aquilo mesmo que convoca tem o "poder" de arrancar-nos de nossos afazeres e dispor-nos perante o nosso próprio ser-livre para... Não se trata, pois, de "reservarmos tempo ao pensar", como que nos liberando de modo meramente negativo de afazeres quaisquer para posteriormente retomá-los ou não, mas de velarmos a sua possibilidade, liberando-nos de modo essencial, permitindo que o próprio pensar se libere. Isso nos deve ensinar que não temos poder sobre o pensamento como se fôssemos capazes de lhe dizer "Que venha agora, pois estou pronto!". Por outro lado - e isso não é menos importante, talvez mesmo o seja mais! -, nada disso significa que o pensamento não possa ser despontencializado, razão pela qual escrevemos "poder" entre aspas. Em verdade, eis o que mais comumente se dá. Em nossa fuga do nada, em nosso horror ao absurdo, em nossa angústia, originariamente já sempre nos ocupamos de modo a preencher toda a existência com o mais desértico vazio de pensamento. 
Somos chegados a um ponto crucial de nosso problema: a ciência é prontamente convertida em "pensamento" mais legítimo, o único legal, posto que dirigido por regras. Tranquilizadoras e asseguradoras, além de conformadas à e pela atitude espiritual natural, à e pela impessoalidade cotidiana, a precisão e a objetividade das ciências despontencializam o pensar mais próprio. Arrancando à força, do ente, uma voz mais alta e capaz de abafar o apelo da consciência, a ciência repele o silêncio existencial e aniquila a mudez do mundo. O mundo mudo como que exige da razão um ventríloquo - este, o papel da ciência a despeito de toda a sua inquestionável utilidade e comodidade (valores esses que não pretendemos recusar). Como já dissera Kierkegaard (1962, p. 196): "Mesmo terrível, [...] a palavra guarda sempre o seu poder de libertação; todo o desespero, todo o horror do Mal condensados numa só palavra, nunca são tão horríveis como o silêncio" ${ }^{12}$. Estas palavras fazem lembrar de imediato a epígrafe ao filme O enigma de Karper Hauser, de Herzog. Rosset (2000, p. 43-55) também tematiza, no primeiro capítulo da segunda parte de seu primeiro livro, O mundo e seus remédios, essa mudez do mundo, e precisamente no contexto de sua própria análise da angústia. Diz ele, por exemplo:

Esta presença silenciosa do mundo é uma angústia e um suplício no homem cuidadoso em compreender o que admira ou que odeia. Nenhuma dúvida de que esta angústia moral seja a origem do cuidado importuno de inteligibilidade que anima a maior parte das filosofias, e em primeiríssimo lugar a de Platão. Antes da busca socrática por ordem e certeza, antes de seu desejo de conhecimento, há uma angústia perante um mundo que não fala. (Rosset, 2000, p. 49).

Mais explicitamente do que Schopenhauer, e mesmo do que Heidegger, Adorno e Horkheimer, em sua obra Begriff der Aufklärung [O conceito de esclarecimento], talvez sejam os primeiros a remeter o próprio começo da filosofia à angústia não segundo o seu sentido estritamente ontológico, mas epistemológico, ou mesmo sociológico. Com efeito, como Rosset, não se trata exatamente de uma angústia originária, mas, ainda assim, uma angústia na vida.

12 A palavra é, contudo, ambígua. Comparar com a passagem de O desespero humano: “a pior descrição duma coisa horrível, jamais aterrorizará tanto a inocência como a reflexão o pode fazer com uma palavra hábil, lançada como que distraidamente, mas contudo calculada sobre qualquer vago perigo; sim, o maior pavor que se possa dar à inocência, é insinuar-lhe, sem falar disso, que ela sabe muito bem de que se trata" (Kierkegaard, 1979 , p. 205). Perfeitamente adequada à proibição divina, esta passagem indica que a palavra pode ser tranquilizante desde que determinada; quando ameaçadoramente vaga, na inocência, produz desespero. Em verdade, as afirmações de Kierkegaard não se opõem; também nessas, o terror provém do deixar em silêncio o essencial, mantendo o seu sentido como mera possibilidade. 
No mundo luminoso da religião grega sobrevive a turva indiferenciação do princípio religioso que, nas mais antigas fases conhecidas da humanidade, era venerado como mana. Originariamente [Primär], indiferenciado é tudo aquilo que é desconhecido, estranho, aquilo que transcende o âmbito da experiência, aquilo que nas coisas excede o seu existir antecipadamente conhecido [was an den Dingen mehr ist als ihr vorweg bekanntes Dasein]. O que aqui é experimentado como sobrenatural pelo primitivo não é a substância espiritual, em oposição à material, mas o entrelaçamento do natural em face do membro singular isolado. O grito de terror que acompanha a experiência do insólito fica sendo o seu nome. Ele fixa a transcendência do desconhecido diante do que é conhecido e converte assim o tremor em santidade. A duplicação da natureza em aparência e essência, ação e força, que faz com que tanto o mito como a ciência venham a ser possíveis, provém da angústia [Angst] do homem, cuja expressão se torna explicação. (Adorno; Horkheimer, 2005, p. 30-31).

Neste trecho, ainda que não trate explicitamente da problemática existencial propriamente dita, certamente a supõe. Temos de volta o "singular isolado" em face da terrível angústia do "indiferenciado", da transcendência que, como tal, excede todo dualismo categorial. Religião e filosofia têm ambas a sua origem (a sua possibilidade) na angústia da "experiência do insólito", cuja tranquilização coincide com a sua racionalização. A angústia se expressa como explicação, como porquê. As palavras de Adorno e Horkheimer não são menos estimáveis por não estarem focadas na ontologia ou no problema da metafísica tal como entendido por Heidegger. Pelo contrário, a nosso ver, servem-lhe de complemento de tal maneira que a obra de Schopenhauer jamais satisfaria a contento em razão do próprio contexto em que veio à luz. Conhecedor de Schopenhauer, Kierkegaard, Nietzsche e Heidegger, Adorno não parece deixar de lado as suas respectivas contribuições para o pensamento acerca do começo da ciência e da religião. Fazendo mito e filosofia provirem da angústia, Adorno e Horkheimer, por assim dizer, inserem a angústia na história e, de certo modo, dão a pista para uma compreensão do privilégio do espírito grego que é irredutível ao sociologismo ou ao historicismo. Interessa-lhes o fundo oculto do comportamento do Ocidente para com o mundo da vida que desembocará na idelogia da racionalidade técnica - isto é, instrumental ${ }^{13}$-, por eles denominada iluminismo, ou esclarecimento, que de modo algum consiste em um período histórico, mas em uma atitude do homem perante o mundo. Por essa racionalização, o caos de um mundo regido por deuses voluntariosos é ordenado sob

13 Cf. Adorno; Horkheimer, 2005, p. 48: “[...] a própria razão tornou-se mero instrumento auxiliar do aparato econômico que tudo abrange. Ela serve de ferramenta universal que se presta à fabricação de todas as outras [...]". 
princípios primeiros e universais que servem de fundamento a sistemas, esquemas e cálculos. A atitude iluminista consiste no empenho em tudo saber e dominar mediante a destruição do desconhecido por sua redução ao conhecido, uma fuga da transcendência.

O homem tem a ilusão de se ter libertado do medo quando já não há mais nada de desconhecido. [...] O iluminismo é a angústia mítica que se tornou radical. A imanência pura do [positivismo], seu produto último, é algo como um tabu universal. Lá fora não deve haver mais nada, pois a mera representação do lá fora é a verdadeira fonte da angústia. (Adorno; Horkheimer, 2005, p. 32).

Desse modo, e por isso a relevância de seu célebre ensaio para nós, a angústia por eles delineada, embora não seja a mesma heideggeriana, inserida em uma filosofia dos humores, ou a kierkegaardiana, pertinente à doutrina da vivência autêntica do cristianismo, guarda com ambas uma clara afinidade; é-lhes paralela. É possível contestar se tais "angústias", paralelas, se encontram ou ao menos se refletem. $\mathrm{O}$ fato de a angústia das representações indeterminadas descrita por Adorno e Horkheimer apresentar afinidade com relação à angústia como disposição fundamental não deve ser entendido como algo casual, tanto menos, a princípio, como mera apropriação conceitual. E se, afinal, não há apenas uma angústia? Por que não pensarmos que a angústia da experiência do insólito remete de modo privilegiado à angústia do ser-livre como tal? Kierkegaard, tendo sido o primeiro a tematizar a angústia, foi o único a fazer uma distinção fundamental à compreensão desse impasse, distinção que desapareceria na obra de Heidegger - trata-se da diferença de princípio entre angústia objetiva e angústia subjetiva.

A angústia objetiva é a do homem genérico colocado, pelo próprio fato da existência, diante da possibilidade de poder, em outras palavras, de sua liberdade; é a angústia pela qual o pecado entrou no mundo. A angústia subjetiva é a do homem concreto que imerge em seu próprio possível, que experimenta pessoalmente "a vertigem da liberdade" por meio de seus atos e de seus pecados. (Le Blanc, 2003, p. 82).

Essa última é a que denominamos "angústia do conhecimento" - derivada, é verdade, mas, por isso mesmo, a mais presente a nós e menos notada: a angústia subjetiva é precisamente aquela que acomete o indivíduo determinado pós-Adão.

No homem posterior a Adão, a angústia é mais refletida. Por outras palavras, o nada que era objeto da angústia como que devém cada vez mais qualquer coisa. Não pretendemos que realmente devenha, nem que 
signifique na realidade qualquer coisa, como não dizemos que ao nada deva substituir-se o pecado ou seja o que for [...]: tudo isso só existe em função da liberdade e não existe senão quando o indivíduo instaura, com o salto qualitativo, o pecado. Portanto, o nada da angústia representa, neste caso, um como que complexo de pressentimentos refletidos sobre si mesmos e aproximando-se cada vez mais do homem, embora, no fundo, ainda nada signifiquem na angústia; todavia - note-se bem - não um nada que seja indiferente ao indivíduo, mas um nada em comunicação viva com a ignorância da inocência. Aquela reflexão equivale a uma prédisposição que, antes de ser cometida a falta, significa essencialmente nada; já a partir do momento em que, com o salto qualitativo, o homem devém culpado, a reflexão aparece como condição prévia em que o homem se apoia para remontar além de si mesmo, porquanto o pecado se auto-pressupõe não antes de ser instaurado (o que corresponderia a uma predestinação) mas desde que o foi. (Kierkegaard, 1962, p. 94-95).

Significa dizer que, depois da queda, o homem reiteradamente se vê confrontado à dívida para com a sua própria liberdade. "A angústia é definida a partir de então como a experiência vivida da possibilidade" (Le Blanc, 2003, p. 81). Como indivíduo, um eu, o sujeito agora se angustia não apenas com o puro nada que o punha, antes do salto, em vertigem à beira do abismo, mas é como que a ele remetido a cada vez que a sua liberdade se vê confrontada ao que lhe pertence: estar em face do indeterminado. A dívida é comum a todos, mas, a cada vez em que se exige da liberdade uma decisão, retorna o seu peso.

Se o objeto da angústia for uma coisa qualquer [que, encarada sob o ângulo essencial da liberdade, tenha uma significação], não haverá salto mas apenas uma transição quantitativa [que transtorna todos os conceitos]. O indivíduo após Adão pode muito bem possuir qualquer coisa mais relativamente a Adão e até algo mais ou algo menos relativamente aos outros homens, que nem por isso a verdade essencial deixa de ser esta: o objeto da angústia é sempre um nada. (Kierkegaard, 1962, p. 116-117).

O nada está sempre ali em nós na medida em que nos pertence. Se, uma vez decaídos, nos tornássemos absolutamente determinados como o são os demais entes, jamais nos acometeria a vertigem da liberdade. O ser-livre jamais deixa de ser nossa essência, o que se mostra no fato de a cada vez podermos nos ver confrontados por ele, sob a exigência de decisão de ainda fugir ou encará-lo, assumindo-nos. Em tal encruzilhada, habitualmente tomamos a primeira via, mas isso jamais garantirá a perpetuidade do asseguramento. Como nos diz Le Blanc (2003, p. 50-51), as alternativas trazem consigo algo de paralisante sempre que "qualquer escolha parece impossível", mesmo porque nenhuma 
oferece garantia de sucesso: "Uma ilusão irá representá-las a nós como boas notícias ou boas promessas, mas qualquer alternativa carrega consigo felicidade e infelicidade, sucesso ou fracasso, vida ou morte. As possibilidades positivas não têm mais probabilidade de se realizar do que as possibilidades negativas". A angústia subjetiva descrita por Kierkegaard provém da insistência do nada no mundo da vida, em que o indivíduo já sempre se encontra situado, estando todo mal-estar que lhe é característico essencialmente ligado ao desconhecimento, assim como a angústia objetiva se liga à ignorância originária - em ambos os casos, vemo-nos confrontados à possibilidade de saber, que sempre remete à possibilidade da falta.

O principal problema com a vida real é que ela não nos dá acesso aos fundamentos da existência, uma vez que é uma "vida que foge do fundamental"14. "Viver é importar-se, especialmente no sentido de facilitar as coisas para si, escapando". O mundo com o qual me importo me encobre. E Heidegger quer gerar "vigilância do Dasein sobre si mesmo". Certas situações existenciais, como a angústia e o tédio, abremse para um movimento de reação, já que o Dasein, em tais situações, não pode mais contar com o mundo, sendo brutalmente jogado de volta em si mesmo. (Svendsen, 2006, p. 128-129).

Todavia, a tendência, radicada na fuga, para "contar com o mundo" comumente prevalece, e aí reside particularmente o interesse na ciência e na religião. Ambas, cada qual a seu modo, vêm oferecer explicações, porquês, causas para a existência, para o próprio mundo da natureza como um todo. Aristóteles mostrou com correção a necessidade de uma causa-primeira a fim de que a própria possibilidade de explicação fosse sustentável, ou seja, de que o regresso ao infinito pudesse ser eliminado. A mesma tese, que em si mesma diz respeito antes de tudo a uma exigência do intelecto, em sua apropriação por Tomás de Aquino, consolidase como exigência da natureza como tal, levando inexoravelmente à determinação da existência de Deus e estimada como prova. Se, por um lado, podemos reconhecer aí uma evidente petição de princípio, por outro, somos obrigados a admitir que do assentimento a essa tese depende toda possibilidade de conhecimento. Em seu "racionalismo absoluto", conforme a denominação de Chauí (2006), Espinosa adere ainda mais radicalmente à tese do conhecimento pelas causas. Afinal, reconhecendo o caráter abstrato de gêneros e espécies, para Espinosa, a própria definição real ou ideia verdadeira do objeto consiste no conhecimento

14 Esta citação, como as seguintes, é retirada das Interpretações fenomenológicas de Aristóteles, de Heidegger. 
de causas e efeitos necessários pelos quais cada coisa é o que é, dotada de tais ou quais propriedades, a isso se acrescentando um imenso otimismo quanto às possibilidades do intelecto (Chauí, 2006, p. 32-38). Todavia, e Kant o mostrou, destruindo com isso toda forma de realismo, tal conhecimento pelas causas, ainda que seja o único seguro, não passa de representação. O lado perverso da crítica kantiana a esse respeito consiste, porém, em haver reduzido toda possibilidade de pensamento aos limites do conhecimento representacional, isto é, segundo causas. A devida recondução do problema da causalidade ao âmbito estrito do conhecimento representacional vem acompanhada do exagero rigorista. A análise de Nietzsche sobre esse ponto, em seu Assim falou Zaratustra, é muito bem sintetizada por Machado (1997, p. 100):

Como "Nas ilhas bem-aventuradas", que explicitava o desejo de verdade como desejo de "que tudo se transforme no que pode ser humanamente pensado, humanamente visto, humanamente sentido", a vontade de potência niilista é agora [em "Do superar a si mesmo"] caracterizada como vontade de tornar pensável todo o existente, tudo o que é (alles seiende); de submeter, dobrar, o mundo à vontade de potência do homem; de adequar a vida ao pensamento humano, torná-la seu "espelho", seu "reflexo". Em última análise, a vontade de potência dos "mais sábios" é vontade de projetar sobre o mundo, sobre a vida, valores humanos estabelecidos em termos de bem e de mal.

Desse modo, a crítica kantiana, em verdade, consolida de uma vez por todas o mito da causa-primeira - dizemos "mito" por se tratar de uma hipótese indemonstrável, mas sem a qual, como já prevenira Aristóteles, nada pode ser representado como verdadeiro. Não apenas Heidegger, mas também Adorno e Horkheimer concordam com Nietzsche que essa "vontade de tornar pensável" é inerente a uma vontade de domínio, controle e asseguramento. Nessa discussão, não podemos esquecer as palavras de Hume, que, em vez de significarem uma recusa da ciência, permite-nos estimá-la de um ponto de vista meramente utilitário e mesmo, a essa altura, reconhecer nela, como na ética, uma exigência existencial. Diz ele na segunda parte da seção VII de sua Investigação...:

[...] se há alguma relação entre os objetos que visamos a apreender com perfeição, é aquela de causa e efeito. Nela se fundamentam todos os nossos raciocínios sobre as questões de fato ou de existência. Apenas por meio desta relação podemos ter alguma segurança sobre os objetos distanciados do atual testemunho de nossa memória e dos sentidos. Esclarecer-nos como controlar e regular os eventos futuros através de suas causas é a única e imediata utilidade de todas as ciências. (Hume, 1996, p. 86; grifos nossos). 
Consideramos central o papel de Kant neste processo.

A dominação da natureza delineia o círculo para o qual o pensar foi exilado pela Crítica da razão pura. Kant ligou a doutrina do trabalhoso e ininterrupto progresso sem fim do pensar à insistência sobre a sua insuficiência e eterna limitação. A resposta que [dá] é um oráculo. Não há ser no mundo em que a ciência não possa penetrar, mas aquilo em que a ciência pode penetrar não é o ser. Segundo Kant, o juízo filosófico visa à novidade e contudo não conhece nada de novo, pois limita-se a repetir continuamente aquilo que a razão desde sempre implantou no objeto. Mas, a esse pensamento, garantido nos diversos ramos da ciência em face dos sonhos de um visionário, é apresentada a conta: a dominação mundial sobre a natureza vira-se contra o próprio sujeito pensante, dele nada mais resta do que justamente aquele eternamente idêntico eu penso que deve poder acompanhar todas as minhas representações. (Adorno; Horkheimer, 2005, p. 43-44).

Infelizmente, Schopenhauer mantém até certo ponto a incontornabilidade do princípio de causalidade, no que concerne ao ponto de vista do mundo como representação, mas já procura superá-lo denunciando a sua pouca monta, no que será imediatamente seguido por Nietzsche. Deve ser notado, ainda, que a redução do pensamento às condições de possibilidade de representação não apenas puseram em perigo a sua essência, como tão repetidas vezes alertou Heidegger, mas também que esse perigo já cresce há muito tempo como empobrecimento do pensado. Nesse sentido, quando a causa-primeira, de motor imóvel, passa a ser identificada com o Deus-Criador, ou especialmente com o Deus de Espinosa, tem-se clareza sobre quão longe chegou a fuga do nada da angústia.

Assim, quando todo o real se apresenta à luz do nexo de causa e efeito, até Deus pode perder, nesta representação, toda santidade e grandeza, o mistério de sua transcendência e majestade. À luz da causalidade, Deus pode degradar-se a ser uma causa, a causa efficiens. Ele se torna, então, até na teologia, o Deus dos filósofos, daqueles que medem o desencoberto e o coberto de acordo com a causalidade do fazer, sem pensar de onde provém a essência da causalidade.

Do mesmo modo, [...] a natureza, expondo-se, como um sistema operativo e calculável de forças [,] pode proporcionar constatações corretas mas é justamente por tais resultados que o desencobrimento pode tornar-se o perigo de o verdadeiro se retirar do correto". (Heidegger, 2007a, p. 29).

Eis que neste trecho da conferência "A questão da técnica" também se vislumbra o centro da crítica heideggeriana da vontade (como 
operari $)^{15}$ e da verdade (como representação). A vontade é tematizada, então, como um poder, sendo nesse sentido que, para Heidegger, Nietzsche representará o acabamento da metafísica moderna, na medida em que, em sua obra, a vontade de poder assume a sua expressão máxima, não por consolidar de uma vez por todas a crença na liberdade do operari, mas, inversamente, por sacrificá-la à absolutização de um querer universal e impessoal. A vontade de poder constitui, como a vontade schopenhaueriana, todo ente, mas ao mesmo tempo não é nenhum ente em particular, não é um Eu, não é Deus, não é ordem, não é "nada". Nesse ínterim, em que se pensa o mundo como vontade de poder, mesmo contra o que defende Nietzsche ou Schopenhauer, todo ente é reduzido à representação a fim de que seja "pensado" segundo causas e, assim, seja apropriado pelo entendimento. Enclausurando o pensamento em representações necessariamente regidas pelo princípio de causalidade, não apenas se fecha o pensamento do essencial como se o despreza, barrando, por conseguinte, a disposição que lhe é própria e, finalmente, reduzindo o fenômeno da verdade às produções do intelecto. A experiência da verdade se perde e, com ela, a liberdade para o pensamento em sentido próprio - a verdade, como constata Nietzsche, converte-se em valor e, como tal, é submetida a uma moral. A morte de Deus representa, desse modo, a inevitável fatalidade decorrente da hipertrofia do princípio de causalidade, que não é mais pensado senão como causa-primeira ou causa-de-si-mesmo, como princípio, ao mesmo tempo, da natureza e da moralidade. Tal hipertrofia é levada ao extremo em que Deus deixa de ser necessário, figurando apenas como objeto de crença, graças a duas teses fundamentais: a do livre-arbítrio e a de que todo nosso conhecimento não passa de representação. Apenas à primeira vista é paradoxal que o piedoso Kant, seguindo a tradição de um outro,

15 A interpretação da vontade como "operari" está relacionada à "causalidade do fazer" e, portanto, à noção de "causa efficiens". Nesse sentido, diz respeito à possibilidade da liberdade de fazer/agir/atuar fundada em uma liberdade da vontade fundada, por sua vez, em uma liberdade de arbítrio. Arbitrar e fazer já supõem a cisão metafísica entre os âmbitos do teórico e do prático, o que, para Heidegger, encobre o sentido ontológico mais originário da liberdade e sua verdade. No contexto do mundo técnico em que vivemos, nosso fazer é essencialmente marcado pelo cálculo que tem em vista a apropriação exploratória de todo ente e o provimento de recursos, enquanto que a liberdade diz respeito, antes, à liberação do ente em seu ser próprio, o que se permite no pensar, não no calcular ou no fazer. É nesse sentido que se distinguem o fazer técnico (techné) e a produção poética (poiesis): enquanto a techné é um fazer que atualiza o ente, operando nele uma transformação pela qual se extraem e desenvolvem as suas potencialidades, a poiesis libera o ente em sua essência dando-lhe voz, deixando-o ser. Representar o fazer (operari) como causalidade é reduzi-lo ao âmbito das ocupações, perdendo-se de vista a essência da causalidade, da vontade e do próprio fazer, incorrendo-se no esquecimento da verdade em prol do correto previsível e apropriável. 
Descartes, tenha nas mãos o sangue do Deus morto. Dizemos "apenas à primeira vista", porque tanto um como o outro estrategicamente impediram que Deus fosse destruído pela ciência antes de garantirem que esta se dirigisse em conformidade aos pressupostos morais da fé cristã. Trata-se de uma obra que levou séculos para ser concluída, não sem conflitos, remontando ao nominalismo de Ockham - que separava em domínios incomensuráveis teologia e filosofia - e passando pela laicização do Estado, com expressão paradigmática na obra política de Locke, onde a religião é necessária para a consciência moral, mas, ao mesmo tempo, a fé não mais pertence ao âmbito público, e sim ao privado, pelo que se pregava a tolerância religiosa. Em meio a isso, o panteísmo de Espinosa consiste em consequência necessária de seu conceito de substância, não podendo ser compreendido à parte de sua querela contra as "superstições religiosas" e de sua teoria da imaginação e das ideias inadequadas. O fato de Hegel haver construído todo um sistema sobre o modelo da Santíssima Trindade não representaria mais do que uma chancela final. Deus se tornou tão próximo às representações que se perdeu, pois a sua realidade, exilada na fé individual, passou a consistir em uma existência impotente perante um mundo destituído de graça e mistério. Com Nietzsche, que também nesse aspecto segue de muito perto Schopenhauer, traçando o caminho aberto por Kant - por isso afirmamos que é ironicamente nas mãos deste último que se encontra o sangue divino -, a própria causalidade perde a sua realidade, não passando de representação, de produção humana, apenas a que pode remeter qualquer conceito de "objetividade" ou "explicação".

\section{Referências}

\section{Fontes primárias}

ARISTÓTELES. "Posterior analytics (Analytica posteriora)". Trad. para o inglês de G. R. G. Mure. In: MCKEON, R. (ed). The Basic Works of Aristotle. Introd. de C. D. C. Reeve. Nova Iorque: Modern Library, 2001, p. 108-186.

ARISTÓTELES. Metafísica. Texto grego com tradução ao lado. Trad. para o italiano de Giovanni Reale; trad. Para o português de Marcelo Perine. Edição bilíngue grego/ português. São Paulo: Loyola, 2002, Vol. II.

ADORNO, T. W.; HORKHEIMER, M. "Conceito de iluminismo". In: ADORNO, T. W. Textos escolhidos. Coleção Os Pensadores. São Paulo: Nova Cultural, 2005, p. 17-62.

HEIDEGGER, M. “Que é isto - a filosofia?". In: HEIDEGGER, M. Conferências e escritos filosóficos. Trad. de Ernildo Stein. Coleção Os Pensadores. São Paulo: Nova Cultural, 2000a, p. 21-40.

HEIDEGGER, M. "Que é metafísica?" In: HEIDEGGER, M. Conferências e escritos filosóficos. Trad. de Ernildo Stein. Coleção Os Pensadores. São Paulo: Nova Cultural, 2000b, p. 41-88. Inclui "Posfácio" de 1943 e "Introdução" de 1949. 
HEIDEGGER, M. "O fim da filosofia e a tarefa do pensamento". In: HEIDEGGER, M. Conferências e escritos filosóficos. Trad. de Ernildo Stein. Coleção Os Pensadores. São Paulo: Nova Cultural, 2000c, p. 89-108.

HEIDEGGER, M. "Sobre a essência do fundamento". In: HEIDEGGER, M. Conferências e escritos filosóficos. Trad. de Ernildo Stein. Coleção Os Pensadores. São Paulo: Nova Cultural, 2000d, p. 109-148. Inclui "Prefácio à terceira edição" de 1949.

HEIDEGGER, M. Que é uma coisa? Doutrina de Kant dos princípios transcendentais. Trad. de Carlos Morujão. Lisboa: Edições 70, 2002.

HEIDEGGER, M. Os conceitos fundamentais da metafísica: mundo, finitude, solidão. Trad. de Marco Antônio Casanova. Rio de Janeiro: Forense, 2003.

HEIDEGGER, M. "A questão da técnica". Trad. de Emmanuel Carneiro Leão. In: HEIDEGGER, M. Ensaios e conferências. Petrópolis - Bragança Paulista: Vozes - Edusf, ${ }^{4} 2007$ a, p. 11-38.

HEIDEGGER, M. "A superação da metafísica". Trad. de Marcia Sá Cavalcante Schuback. In: HEIDEGGER, M. Ensaios e conferências. Petrópolis - Bragança Paulista: Vozes - Edusf, ${ }^{4}$ 2007b, p. 61-86.

HEIDEGGER, M. "A coisa". Trad. de Emmanuel Carneiro Leão. Acrescido do posfácio "Carta a um jovem estudante", de 18/06/1950. Trad. de Marcia Sá Cavalcante Schuback. In: HEIDEGGER, M. Ensaios e conferências. Petrópolis - Bragança Paulista: Vozes - Edusf, ${ }^{42007 c, ~ p . ~ 143-164 . ~}$

HEIDEGGER, M. ““... poeticamente o homem habita...'”. Trad. de Marcia Sá Cavalcante Schuback. In: HEIDEGGER, M. Ensaios e conferências. Petrópolis - Bragança Paulista: Vozes - Edusf, ${ }^{4} 2007$ d, p. 165-181.

HEIDEGGER, M. "Aletheia (Heráclito, fragmento 16)". Trad. de Marcia Sá Cavalcante Schuback. In: HEIDEGGER, M. Ensaios e conferências. Petrópolis - Bragança Paulista: Vozes - Edusf, ${ }^{4} 2007 e$, p. 227-249.

HEIDEGGER, M. Ser e tempo. Trad. e apres. de Marcia Sá Cavalcante Schuback. Posfácio de Emmanuel Carneiro Leão. Petrópolis - Bragança Paulista: Vozes - Edusf, $2007 f$.

HUME, D. Investigação acerca do entendimento humano. Trad. de Anoar Félix. Coleção Os Pensadores. São Paulo: Nova Cultural, 1996, p. 17-154.

HUSSERL, E. A ideia de fenomenologia. Lisboa: Edições 70, [s. d.].

KIERKEGAARD, S. A. O conceito de angústia. Trad. de João Lopes Alves. Porto: Presença, 1962.

KIERKEGAARD, S. A. O desespero humano (doença até à morte). Trad. Adolfo Casais Monteiro. Coleção Os Pensadores. São Paulo: Abril Cultural, 1979, p. 187-279.

NIETZSCHE, F. W. Crepúsculo dos ídolos: ou como filosofar com o martelo. Trad. de Marco Antonio Casanova. Coleção Conexões. Rio de Janeiro: Relume Dumará, 2000.

PLATÃO. Theætetus/Sophist - Plato's Works. Trad. para o inglês de Harold North Fowler. Edição bilíngue grego/inglês. The Loeb Classical Library. Cambridge: Harvard University Press, Vol. VII, 2006.

PRÉ-SOCRÁTICOS. Fragmentos, doxografia e comentários. Coleção Os Pensadores. São Paulo: Nova Cultural, 1996.

SCHOPENHAUER, A. Le monde comme volonté e comme représentation. Trad. De A. Burdeau. Paris: Presses Universitaires de France, ${ }^{2} 2004$. 
D. Moraes - Princípio de razão e o "conhecimento das causas"

\section{Fontes secundárias}

BRUM, J. T. O pessimismo e suas vontades: Schopenhauer e Nietzsche. Rio de Janeiro: RocCo, 1998.

CASANOVA, M. A. O instante extraordinário: vida, história e valor na obra de Friedrich Nietzsche. Rio de Janeiro: Forense Universitária, 2003.

CHAUÍ, M. de S. Espinosa: uma filosofia da liberdade. São Paulo: Moderna, ${ }^{2} 2006$.

LE BLANC, C. Kierkegaard. São Paulo: Estação Liberdade, 2003.

MACHADO, R. Zaratustra: tragédia nietzschiana. Rio de Janeiro: J. Zahar, 1997.

ROSSET, C. Le monde et ses remèdes. Paris: Presses Universitaires de France, 2000.

SVENDSEN, L. Filosofia do tédio. Rio de Janeiro: J. Zahar, 2006.

Recebido em 11/09/2011.

Aprovado para publicação em 07/04/2012. 